\title{
KETERKAITAN PROTEIN YANG MENGANDUNG THIOESTER (TEP) DENGAN IMUNITAS DARI NYAMUK ANOPHELES TERHADAP PLASMODIUM
}

\author{
Presticilla D. Irawan ${ }^{1)}$ dan Beivy J. Kolondam ${ }^{1)}$ \\ ${ }^{1)}$ Program Studi Biologi FMIPA, Universitas Sam Ratulangi Manado \\ E-mail: presticilla@ymail.com ; beivy.kolondam@unsrat.ac.id
}

\begin{abstract}
ABSTRAK
Protein thioester (TEP) merupakan promotor terjadinya fagositosis bakteri Gram positif dan Gram negatif dalam sistem imun serangga. Salah satu TEP, yaitu TEP1 pada nyamuk Anopheles berfungsi sebagai faktor komplemen yang membunuh Plasmodium. TEP1 nyamuk disintesis pada hemosit dan disekresikan dari hemolimfa. Hubungan TEP1 dengan protein dan enzim lain dapat menghalangi perkembangan ookista dan ookinet pada lambung nyamuk betina. TEP1 nyamuk terdiri dari dua alel yaitu alel R (refractory/resisten) dan alel S (susceptible/rentan). Efektivitas kematian ookinet pada nyamuk TEP-S hanya $80 \%$ dan pada nyamuk TEP-R terjadi $100 \%$. Respon imun nyamuk beralel $\mathrm{R}$ efektif mematikan Plasmodium, namun nyamuk beralel $\mathrm{S}$ mendominasi populasi.
\end{abstract}

Kata-kata kunci: TEP, Anopheles, plasmodium, immunitas, malaria

\section{CONNECTION OF THIOESTER PROTEIN (TEP) AND IMMUNITY OF ANOPHELES MOSQUITO TO PLASMODIUM}

\begin{abstract}
Protein thioester (TEP) is the promotor of phagocytosis for Gram Posistive and Gram negative bacteria in insects immune system. One of the TEPs, the TEP1 are acting as complement factor to eliminate Plasmodium. TEP1 is syntetized in hemocyte and secreted from hemolymph. The connection of TEP1 with other proteins and enzymes are able to inhibit the oocyst and ookinete in the gastric of female mosquitos. The TEP is consist of two alleles; The R (refractory) and the $\mathrm{S}$ (susceptible). The death of ookinete in TEP-S and TEP-R mosquitos are $80 \%$ and $100 \%$, respectively. Immune respond of mosquitos with R-allele are effective to kill Plasmodium but the $\mathrm{S}$-allele are dominant in the population.
\end{abstract}

Kata-kata kunci: TEP, Anopheles, Plasmodium, immunity, malaria

\section{PENDAHULUAN}

Epidemi penyakit malaria di wilayah tropis dan subtropis dipengaruhi oleh kepadatan vektor pembawa parasit malaria seperti nyamuk Anopheles. Kepadatan vektor tersebut dapat disebabkan oleh kelembaban dan curah hujan yang tinggi pada kedua daerah tersebut (Epstein et al., 1998 dalam Suwito et al., 2010). Malaria merupakan penyebab kematian utama di $75 \%$ di Afrika dan 25\% di Asia Tenggara (Munif, 2009). Penyakit malaria disebabkan oleh Plasmodium yang menyerang hati dan darah inang (Sreenivasamurthy et al., 2013; Arsin, 2012). Pengendalian pada tingkat vektor dan parasit hingga saat ini masih ditekankan pada penggunaan insektisida maupun produksi obat-obat antimalaria. Di sisi lain, terjadinya resistensi parasit terhadap zat kimia dalam insektisida dan obat-obatan yang disebabkan mutasi gen mengakibatkan peluang berkembangnya kemampuan parasit resisten untuk tumbuh dalam tubuh inang sehingga dapat meningkatkan jumlah kasus malaria (Simamora dan Fitri, 2007).

Penelitian pada tingkat genom dapat menjadi salah satu cara untuk mengontrol 
penyakit malaria. Banyak penelitian mengenai genom pada Anopheles menghasilkan gen yang potensial yang memiliki fungsi imunitas bagi nyamuk untuk menghilangkan berbagai mikrobiota, salah satunya Plasmodium. Beberapa penelitian diantaranya yaitu dikutip dari Li et al. (2013) berupa gen reseptor (pendeteksi) yang memiliki kemampuan untuk menghalangi pembentukan oosit Plasmodium seperti leucine-rich-repeats protein (APL1C dan LRIM1), protein dalam golongan fibrinogen (FREPs dan FBNs), protein yang mengandung thioester (TEPs), dan C-type lectins (CTLs).

TEP1 (Thioester-containing Protein 1) adalah glikoprotein yang dihasilkan dari hemosit (sel darah nyamuk). Dalam imunitas nyamuk Anopheles betina, TEP1 berfungsi melawan infeksi mikroorganisme, termasuk sel Plasmodium. Protein TEP1 nyamuk berperan sebagai zat komplemen (zat yang dapat melawan infeksi) yang dapat membuat sel bakteri Gram positif dan bakteri Gram negatif mengalami fagositosis (Levashina $e t$ al., 2001). Peran yang lain ialah interaksi TEP1 dengan protein lain seperti APL1C (Anopheles Plasmodium responsive leucinerich repeat 1 C) dan LRIM1 (Anopheles gambiae leucine-rich repeat immune protein), serta enzim seperti HPX2 (heme peroxidase) dan NOX5 (NADPH oxidase 5), yang dapat mencegah perkembangan sel Plasmodium (Oliveira et al., 2012; Povelones et al., 2009).

Peran TEP1 tersebut berkembang dengan munculnya publikasi mengenai alel TEP1 yang bersifat rentan (TEP1-S) dan resisten (TEP1-R) terhadap infeksi Plasmodium. Selain pada nyamuk betina, TEP1 juga terdapat pada nyamuk jantan, di mana diekspresikan pada testis. TEP1 dan alelnya dalam penelitian Pompon dan Levashina (2015) memiliki peran untuk menentukan fertilitas nyamuk jantan. Peran TEP1 pada nyamuk jantan secara tidak langsung berkaitan dengan penghasilan keturunan betina yang membawa kedua sifat tersebut. Ini berpotensi menjadi solusi langkah selanjutnya untuk pengendalian penyebaran penyakit malaria pada tingkat vektor.

\section{IMUNITAS SERANGGA DAN PROTEIN YANG MENGANDUNG THIOESTER (TEP)}

Kelas Insekta (Invertebrata) tidak memiliki respon imun adaptif seperti hewan Vertebrata, sehingga hewan ini menggunakan kekebalan bawaan (innate immunity) untuk imunitasnya (Christophides et al., 2002). Kekebalan bawaan Insekta diperlukan dalam melawan mikroorganisme yang masuk ke dalam tubuhnya (Levashina et al., 2003). Respon imun pada Insekta terdiri atas respon sel (cellular reactions) dan respon humoral (humoral reactions). Respon humoral terdiri atas melanisasi, penggumpalan hemolimfa, dan sintesis peptida antimikroba. Respon sel, dalam hal ini mikroorganisme parasit atau sel apoptosis, dapat mengalami fagositosis, terperangkap dalam formasi nodul, dan kapsulasi oleh hemosit (Vilmoz dan Kurucz, 1998).

Protein thioester (TEP) terdapat dalam sel banyak spesies nematoda, insekta, moluska, pisces, aves, dan mamalia. TEP memiliki karakteristik sekuens homolog, termasuk rantai intra $\beta$-cysteinyl- $\gamma$-glutamyl thioester, dan kecenderungan menghasilkan interaksi yang sensitif terhadap konformasi ikatan ganda, sangat reaktif, dan mudah dihidrolisis oleh air (Blandin dan Levashina, 2004; Levashina et al., 2003).

TEP pada insekta pertama kali ditemukan pada lalat buah Drosophila melanogaster. Lagueux et al. (2000) membandingkan sekuens Drosophila dengan sekuens asam amino rantai $\alpha$ pada sekuens komplemen C3 manusia. Dari penelusuran tersebut dihasilkan ada lima gen yang memiliki kesamaan pada protein thioester dengan gen pada kelompok C3 dan a2M. Dari kelima gen tersebut hanya 4 yang termasuk dalam TEP, yang masing-masing diberi kode TEP1, TEP2, TEP3, dan TEP4. Ekspresi gen TEP larva dan lalat dewasa berada pada level rendah, namun ekspresi mengalami peningkatan ketika terjadi imunitas. Salah satu gen, yaitu TEP1, diproduksi di lemak tubuh.

Penelitian imunitas protein thioester nyamuk Anopheles gambiae dilakukan oleh Levashina et al. (2001) terhadap bakteri. Eksperimen dilakukan dengan menginkubasi bakteri Staphylococcus aureus dan Eschericia coli pada medium aTEP1 (protein thioester pada Anopheles) terkondisi MA dan 
tanpa MA, kemudian diikuti dengan proses immunobloting pada ekstrak dinding sel bakteri, menghasilkan adanya sinyal aTEP1 pada dinding sel. Hasil ini mengindikasikan adanya ikatan thioester yang terbentuk antara TEP1 dengan sel bakteri.

TEP yang berikatan dengan sel bakteri dapat berperan sebagai promotor untuk mendorong terjadinya fagositosis. Dari uji selanjutnya yang dilakukan dengan menggunakan sel nyamuk 5.1* dan bakteri (Gram negatif: Eschericia coli, Serratia marcescens, Salmonella typhimurium; Gram positif: Bacillus subtilis, Micrococcus luteus, Staphylococcus aureus) dengan penanda fluorescent yang diinkubasi pada medium terkondisi aTEP1 serta diikuti dengan proses dsRNA knockout pada TEP1. Nilai PI (phagocytic index/indeks fagositosis) pada bakteri Gram negatif lebih tinggi daripada bakteri Gram positif, mengindikasikan fagositosis dengan aTEP1 terjadi pada bakteri Gram negatif dibandingkan dengan bakteri Gram positif (Levashina et al., 2001).

\section{PROTEIN TEP1 PADA NYAMUK BETINA}

TEP1 pada nyamuk Anopheles (aTEP1) memiliki massa molekul sebesar 165 kDa. Sekuens TEP1 terdiri dari segmen Nterminal dengan signal peptida yang bersifat hidrofobik. Seperti golongan protein thioester lain, TEP1 disintesis oleh hemosit lalu disekresikan dari hemolimfa (Levashina et al., 2003).

Fungsi imunitas gen TEP1 pada nyamuk Anopheles gambiae pada awalnya dijelaskan pada nyamuk betina. Menurut Blandin et al. (2004), TEP1 merupakan faktor yang terlibat untuk membunuh parasit pada nyamuk dan menentukan kapasitas vektor nyamuk. TEP1 mengikat permukaan ookinet setelah ookinet melewat jaringan epitel lambung. Ikatan tersebut berhubungan dengan dua puncak regulasi transkripsi. Ikatan langsung TEP1 tersebut didemonstrasikan dengan penggunaan strain Plasmodium berghei yang mengekspresikan GFP (Green fluorescent protein). Ookinet yang berikatan dengan TEP1 kehilangan GFP sebagai penanda vital, kemudian terjadi perubahan morfologi secara abnormal.

Kematian parasit tersebut dikontrol oleh protein lain selain TEP1. Spekulasi menyebutkan TEP1 berfungsi sebagai faktor komplemen. Protein lain tersebut dapat membuat TEP1 berikatan pada parasit. Sebuah penelitian lain menyimpulkan pembentukan kompleks untuk aktivasi sistem komplemen pada hemolimfa dengan interaksi TEP1 dengan protein APL1C (Anopheles Plasmodium responsive leucine-rich repeat 1 C), dan LRIM1 (Anopheles gambiae leucinerich repeat immune protein), dapat menghalangi perkembangan ookista Plasmodium pada lambung. Kedua protein tersebut merupakan protein antagonis yang membentuk jembatan disulfida dengan berat molekul yang tinggi dalam sirkulasi hemolimfa (Povelones et al., 2009). Hubungan enzim HPX2 (heme peroxidase) dan NOX5 (NADPH oxidase 5) sebagai mediator nitrasi jaringan epitel lambung dengan TEP1 pada Anopheles gambiae dapat menargetkan ookinet Plasmodium serta membuat sel tersebut terdeteksi sistem komplemen dan mengalami lisis (Oliveira $e t$ al., 2012).

\section{ALEL GEN TEP1 DAN IMUNITAS NYAMUK ANOPHELES TERHADAP PLASMODIUM}

Protein TEP1 nyamuk dikode dua alel yang berbeda, yaitu alel $\mathrm{R}$ (refractory/resisten ) dan alel $\mathrm{S}$ (susceptible/rentan). Perbedaan peran kedua alel (S dan R) dalam membunuh parasit diuji dengan menghilangkan ekspresi TEP1 menggunakan eksperimen $d s R N A$ knockdown, menghasilkan jumlah oosit dalam tubuh nyamuk betina yang rentan mengalami peningkatan 5 kali lipat di perut, dan pada nyamuk resisten eksperimen tersebut mencegah melanisasi parasit, sehingga resistensi nyamuk tersebut hilang (Blandin et al., 2004).

Parasit melakukan kontak dengan komponen hemolimfa setelah melewati epitel lambung. Salah satu komponen adalah TEP1, mengenal ookinet lalu mengikat sel tersebut. Kematian parasit tersebut ditentukan dengan cara lisis maupun dengan melanisasi. Blandin et al. (2004) menjelaskan dua model respon imun berdasarkan alel TEP. Berdasarkan perbedaan efektivitas kematian ookinet, hanya $80 \%$ ookinet yang mati pada nyamuk $\mathrm{S}$ dan $100 \%$ pada nyamuk R. Pada nyamuk S, kematian hanya terjadi pada proses lisis sedangkan pada nyamuk R kematian meliputi 
lisis dan melanisasi. Dua model tersebut dapat dilihat pada Gambar 1.

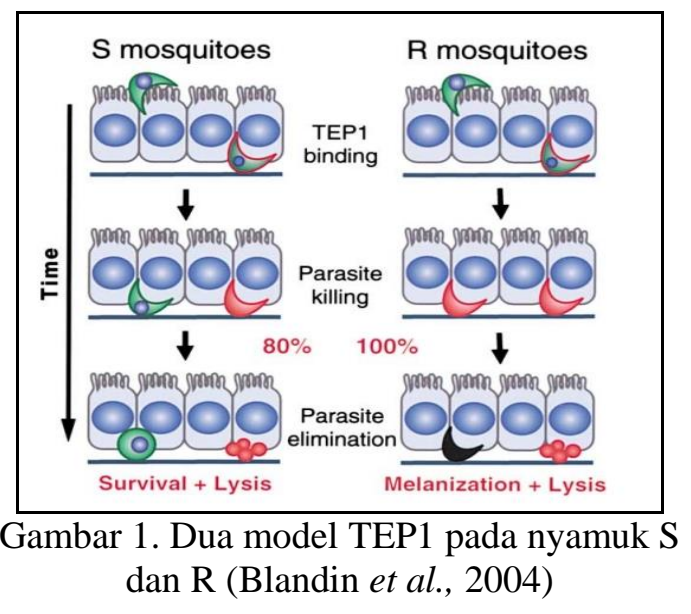

Dari penjelasan dua model tersebut menyebutkan bahwa respon imun dari nyamuk beralel $\mathrm{R}$ efektif mematikan parasit Plasmodium, namun nyamuk dengan alel $\mathrm{S}$ mendominasi populasi dan menjadi vektor yang menyebabkan epidemi malaria di berbagai wilayah. Penelitian terbaru dilakukan oleh Pompon dan Levashina (2015) menjawab fenomena tersebut. Alel TEP1 tertentu memiliki fungsi dalam spermatogenesis jantan, di mana mekanisme yang terjadi adalah TEP1 dapat menandai dan berikatan dengan sel sperma yang rusak.

TEP1 di dalam testis terdeteksi pada spermatogonium dan spermatozoa (kepala dan ekor). Perkembangan nyamuk dari fase larva hingga dewasa mempengaruhi adanya gen TEP1 pada testis. Berdasarkan analisis immunofluorescence pada testis jantan pascakawin yang dibedah, penurunan sinyal TEP1 pada testis terjadi satu minggu setelah dewasa diikuti dengan fase terminasi. Peningkatan spermatogonium dengan sinyal TEP1 terjadi setelah kawin (Pompon dan Levashina, 2015).

Mekanisme pengikatan TEP1 pada sel sperma terjadi dengan mekanisme yang sama dengan TEP1 pada ookinet di lambung nyamuk betina. Salah satu eksperimen dilakukan dengan radiasi untuk menguji pengaruhnya terhadap fertilitas nyamuk jantan. Penggunaan radiasi menyebabkan adanya penurunan fertilitas nyamuk jantan, di mana terjadi peningkatan jumlah sel sperma yang rusak. Hal ini berakibat pada menurunnya produksi telur (ovulasi) pada nyamuk betina dan tingkat penetasan keturunan (hatching progeny) (Pompon dan Levashina, 2015). TEP1 yang berikatan dengan sel sperma yang rusak dibuktikan kembali dari hasil uji dengan mengeliminasi protein LRIM1 dan HPX2 yang terdeteksi pada testis. Hasil menunjukkan hilangnya ikatan TEP1 dengan sel tetapi tidak berpengaruh terhadap ekspresi gen TEP1 (Pompon dan Levashina, 2015). Hal ini membuktikan bahwa TEP1 merupakan faktor komplemen yang membutuhkan interaksi dengan protein (Povelones et al., 2009) dan enzim lain (Oliveira et al., 2012) agar berikatan dengan sel Plasmodium.

Spermatogenesis berakhir dengan proses apoptosis, yaitu kematian sel terprogram. Apoptosis terjadi dengan pembentukan sel apoptosis, yaitu sel embrionik mati dengan nukleus dan sitoplasma yang telah terkondensasi. Setelah itu sel tersebut ditelan oleh sel fagositosis. Uji TUNEL (TdT-mediated dUTP nick-end labelling) dilakukan pada testis kontrol dengan testis keturunan F1 dari perkawinan nyamuk DSX dan nyamuk transgenik $7 \mathrm{~b}$ yang telah dimatikan ekspresi TEP1-nya. Perbandingan hasil uji TUNEL antara menunjukkan bahwa jumlah sel positif apotosis pada testis keturunan F1 (DSX-7b) lebih tinggi. Sehingga ini menunjukkan kemampuan komplemen TEP1 dalam berikatan dengan sel sperma dan mendorong apoptosis sel tersebut (Abrams et al., 1993; Pompon dan Levashina, 2015).

TEP1 nyamuk terdiri dari dua alel, yaitu alel resisten (TEP1-R) dan alel rentan (TEP1-S) yang memiliki perbedaan dari tingkat imunitas terhadap patogen. Uji TUNEL dilakukan pada masing-masing testis nyamuk homozygot beralel S1/S1 (rentan), S2/S2 (rentan), dan R1/R1 (resisten) yang telah dipapar radiasi. Proporsi testis dengan sel-sel yang mengalami apoptosis pada nyamuk S2/S2 paling rendah di antara yang lain (Gambar 2). Hasil ini mengindikasikan bahwa TEP1 alel S2 lebih efektif mencegah radiasi yang menyebabkan penurunan kesuburan nyamuk jantan. Ketiga jenis nyamuk diuji kembali dengan penanda TUNEL pada kondisi normal (tanpa radiasi). Tingkat penetasan keturunan nyamuk S2/S2 paling tinggi (Gambar 3), menandakan nyamuk beralel TEP1 S2 memiliki tingkat fertilitas yang tinggi (Pompon dan Levashina, 2015). 


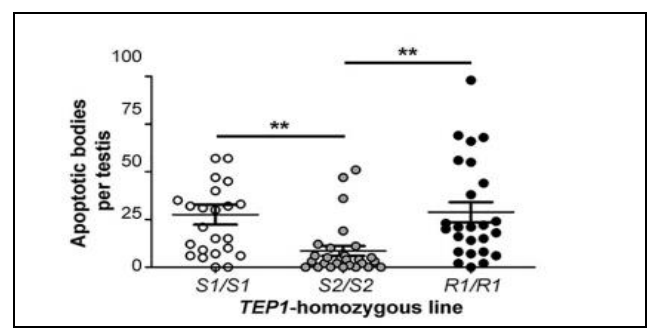

Gambar 2. Proporsi sel-sel apoptosis pada testis setiap alel TEP1, pada satu titik menunjukkan satu testis (Pompon dan Levashina, 2015)

Dengan melihat potensi alel TEP1 tertentu yang dapat membunuh parasit Plasmodium secara efektif, serta hasil penelitian mengenai penyebab keberadaan nyamuk terinfeksi parasit yang disebabkan oleh dominasi alel rentan, maka proyeksi ke depannya adalah bagaimana mengembangkan metode yang efektif untuk membuat alel efektif tersebut masuk dalam populasi alami.

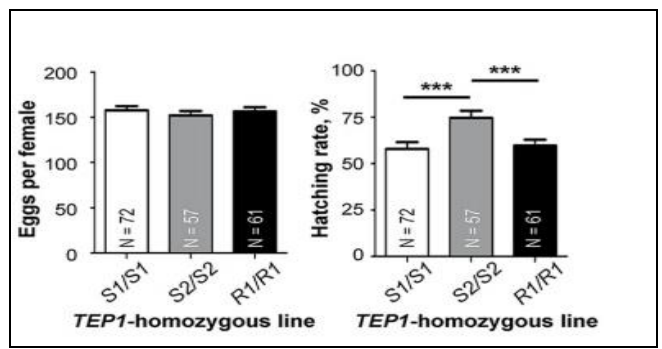

Gambar 3. Tingkat ovulasi dan penetasan larva dari tiga jenis alel (Pompon dan

Levashina, 2015)

Salah satu metode yang dapat dilakukan untuk pengendalian vektor yaitu rekayasa genetika untuk menghasilkan nyamuk Anopheles transgenik yang membawa alel R. Serangga resisten parasit hasil rekayasa genetika memiliki peran dalam populasi sebagai pengganti serangga yang rentan, dan selanjutnya dapat menghilangkan penyebaran penyakit akibat transmisi parasit (Aksoy, 2003). Keberhasilan kontrol genetik dengan metode tersebut tidak terlepas dari penelusuran lebih lanjut tentang struktur populasi secara genetik dan aliran gen vektor tersebut (Collins et al., 2000).

\section{KESIMPULAN}

Gen TEP1 berfungsi sebagai faktor komplemen dalam imunitas nyamuk Anopheles terhadap infeksi Plasmodium. Kedua alel TEP1 memiliki tingkat imunitas yang berbeda di mana alel R (TEP1-R) berpotensi membunuh ookinet Plasmodium dan alel S (TEP1-S) berpotensi menjadi faktor yang membuat nyamuk rentan terinfeksi Plasmodium. Melihat pengaruh TEP1-S yang menyebabkan nyamuk Anopheles rentan terhadap serangan parasit, dominasi TEP1-S dalam populasi nyamuk Anopheles, serta potensi TEP1-R dalam membunuh parasit, penelitian di masa depan dalam rekayasa genetika alel TEP1-R dapat dijadikan solusi untuk mengatasi penyebaran nyamuk Anopheles yang membawa parasit Plasmodium sebagai penyebab penyakit malaria.

\section{DAFTAR PUSTAKA}

Abrams, J.M., White, K., Fessler, L.I., Steller, H. 1993. Programmed cell death during Drosophila embryogenesis. Development 117(1): 29-43.

Aksoy, S. 2003. Control of tsetse flies and trypasonomes using molecular genetics. Veterinary Parasitology 115(2): 125-145.

Arsin, A.A. 2012. Malaria Di Indonesia: Tinjauan Aspek Epidemiologi. Masagena Press, Makassar

Blandin, S., Levashina, E.A. 2004. ThioesterContaining Protein and Insect Immunity. Molecular Immunology 40(12): 903-908.

Blandin, S., Shiao, S.H., Moita, L., Janse, C.J., Waters, A.P., Kafatos, F.C., Levashina, E. 2004. Complement-Like Protein TEP1 is a Determinant of Vectorial Capacity in The Malaria Vector Anopheles gambiae. Cell 116(5): 661-670. 
Christophides, G.K., Zdobnov, E., BarillasMury, C., Birney, E., Blandin, S., Blass, C., Brey, P.T., Collins, F.H., Danielli, A., Dimopoulos, G., Hetru, C., Hoa, N.T., Hoffmann, J.A., Kanzok, S.M., Letunic, I., Levashina, E.A., Loukeris, T.G., Lycett, G., Meister, S., Michel, K., Moita, L.F., Müller, H., Osta, M.A., Paskewitz, S.M., Reichhart, J., Rzhetsky, A., Troxler, L., Vernick, K.D., Vlachou, D., Volz, J., von Mering, C., Xu, J., Zheng, L., Bork, P., Kafatos, F. 2002. Immunity-Related Genes and Gene Families in Anopheles gambiae. SCIENCE 298(5591): 159-165.

Collins, F.H., Kamau, L., Ranson, H.A., Vulule, J.M. 2000. Molecular entomology and prospects for malaria control. Bulletin of the World Health Organization 78 (12): 1412-1423.

Lagueux, M., Perrodou, E., Levashina, E., Capovilla, M., Hoffman, J.A. 2000. Constitutive Expression of A Complement-like Protein in Toll and JAK Gain-of-function mutants of Drosophila. PNAS 97(21): 11427-11432.

Levashina, E.A., Blandin, S., Moita, L.F., Lagueux, M., Kafatos, F.C. 2003. Thioester-Containing of Protostomes. Innate Immunity. Humana Press, New Jersey

Levashina, E.A., Moita, L.F., Blandin, S., Vriend, G., Lagueux, M., Kafatos, F. 2001. Conserved Role of a Complementlike Protein in Phagocytosis Revealed by dsRNA Knockout in Cultured Cells of The Mosquito, Anopheles gambiae. Cell 104(5): 709-718.

Li, J., Wang, X., Zhang, G., Githure, J.I., Yan, G., James, A.A. 2013. Genomeblock expression-assisted association studies discover malaria resistance genes ini Anopheles gambiae. PNAS 110 (51): $20675-20680$.

Munif, A. 2009. Nyamuk Vektor Malaria dan Hubungannya Dengan Aktivitas Kehidupan Manusia di Indonesia. Aspirator 1(2): 94 - 102.

Oliveira, D., Lieberman, J., Barillas-Mury, C. 2012. Epithelial Nitration by a Peroxidase/NOX5 System Mediates Mosquito Antiplasmodial Immunity. Science 335 (6070): 856-859.
Pompon, J., Levashina, E.A. 2015. A New Role of the Mosquito Complement-like Cascade in Male Fertility in Anopheles gambiae. PLOS Biology 13(9): e1002255.

Povelones, M., Waterhouse, R.M., Kafatos, F.C., Christophides, G.K. 2009. Leucinerich repeat preotein complex activates mosquito complement in defense against Plasmodium parasites. Science 324(5924): 258-261.

Simamora, D., Fitri, L.E. 2007. Resistensi Obat Malaria: Mekanisme dan Peran Obat Kombinasi Obat Antimalaria Untuk Mencegah. Jurnal Kedokteran Brawijaya 23(2): 82-91.

Sreenivasamurthy, S., Dey, G., Ramu, M., Kumar, M., Gupta, M.K., Mohanty, A.K., Harsha, HC., Sharma, P., Kumar, N., Pandey, A., Kumar, A., Prasad, T. K. 2013. A compendium of molecules involved in vector-pathogen interactions pertaining to malaria. Malaria Journal 12: 216.

Suwito, Hadi, U.K., Sigit, S.H., Sukowati, S. 2010. Hubungan Iklim, Kepadatan Nyamuk Anopheles dan Kejadian Penyakit Malaria. J. Entomol. Indon. 7(1): 42-53.

Vilmoz, P., Kurucz, E. 1998. Insect immunity: evolutionary roots of the mammalian innate immune system. Immunology Letters 62(2): 59-66. 